\title{
Teachers' Perspectives: Factors That Impact Implementation of Integrated Curriculum in K-3 Classrooms
}

\section{Yao Fu}

Indiana University of Pennsylvania, U.S., y.fu4@iup.edu

\section{Susan Sibert}

Indiana University of Pennsylvania, U.S., susan.sibert@iup.edu

The purpose of this study was to uncover the factors that may influence K-3 inservice teachers' implementation of integrated curriculum (IC). To provide a consistent research base, the broad definition of IC and Jacob's model were adopted to clarify the controversial concept of IC. Survey data were collected from forty-two teachers from ten school districts in Ohio. Results showed that most teachers implemented IC on a regular basis; however, they preferred to use less integrated forms of the curriculum. In addition, the study revealed that though teachers overwhelmingly believed in the effectiveness of IC and their own knowledge and skills on IC, their agreement levels about other factors that might affect IC implementation varied. Teachers' planning time and compatible working hours with their colleagues were identified as the significant predictors affecting teachers' frequency of using IC. Community support, colleague support and teachers' knowledge and skills of implementing IC were found to moderately influence the form of IC most frequently adopted by those K-3 teachers. Educational implications and recommendations for future research are discussed.

Key Words: integrated curriculum, factors, curriculum implementation, teachers' perspectives, early childhood

\section{INTRODUCTION}

Integrated Curriculum (IC) is not new to educational professionals. Its history can be traced back to the 1920s and 1930s when the U.S. witnessed a progressive reform movement in the world of education. Since John Dewey's pioneering integrated approaches to organizing school learning, IC has been widely advocated and used in $\mathrm{K}$ 12 classrooms (e.g. National Association for Core Curriculum, 1984; Lewis \& Shaha, 2003). However, there is as yet no consensus on the meaning of IC and the term is frequently used interchangeably with "interdisciplinary", "transdisciplinary", or "thematic" curriculum (Czerniak, Weber, Sandmann, \& Abhern; Hough \& Clair, 1995; 
Jacobs, 1989; Vars, 1993). The lack of consistent theoretical framework prevents researchers and education professionals from developing a clear understanding of curriculum integration. This, in turn, causes further confusion in teaching practices when teachers attempt to implement IC in their classrooms. As Jacobs (1989) stated, "teachers refer to their 'interdisciplinary unit' when, in fact, their meaning of interdisciplinary unit is 180 degrees different from their colleagues' down the hall”' (p. 6).

Previous research on IC has focused on three primary topics. Some studies have explored the effectiveness of IC. There have been ongoing investigations concerning whether IC can benefit students' learning, such as resulting in higher levels of motivation and academic performance (Lewis \& Shaha, 2003; MacMath, Roberts, Wallace, \& Chi, 2009; Orillion, 2009). Some studies highlighted the importance of inservice and pre-service teachers' competencies to implement IC (Harrell, 2010; Richards \& Shea, 2006). However, fewer studies have probed the conditions that impact curriculum implementation, including collegial relationships, professional training, administrative leadership and many other factors (Meister \&Nolan, 2001; Wallace, Sheffield, Rennie, \& Venville, 2007).

The IC research discussed above indicated that a number of factors are critical to successful curriculum implementation; however, these factors have been examined often in isolation from each other. The present study attempted to conduct a more comprehensive investigation on the related factors that affect implementation of IC in K3 classrooms. Specifically, the researcher intended to uncover how teachers' beliefs in the effectiveness of IC, teacher knowledge and skills to implement IC, as well as other factors beyond teaching may impact their curriculum decisions. Additionally, the study was conducted from teachers' perspectives, which helped to collect teachers' views of IC. Since implementing IC is a complicated and dynamic process that cannot be separated from the complex realities of schooling (Martinello \& Cook, 1994), in-service teachers are a good resource to identify factors that may affect the implementation of IC. Last but not least, the current study was grounded in a consistent theoretical base by adopting the broad definition of IC and Jacobs' (1989) model to clarify the controversial concept of IC.

\section{LITERATURE REVIEW}

In response to the challenge of lacking a clear theoretical framework for IC, the key concept of IC is defined in its broader sense in this study, as a collective term for any curriculum form that deliberately links knowledge associated with more than one subject area. This broad definition is consistent with what Meeth (1978) notes, an emphasis that deliberately identifies the relationship across disciplines. Similarly, Shoemaker (1989) defines IC as education organized in such a way that it cuts across subject-matter lines, and brings together various aspects of the curriculum into meaningful association to focus upon broad areas of study. There are others who also advocate this broad definition. For instance, Gehrke (1998) broadly defines curriculum integration as the following: 
[a] collective term for those forms of curriculum in which student learning activities are built, less with concern for delineating disciplinary boundaries around kinds of learning, and more with the notion of helping students recognize or create their own learning. (p. 248)

To further clarify the concept, Jacobs' (1989) model was used as the basis to categorize different curriculum forms that fall under the umbrella of IC. Jacobs stated that school curricula should provide students with experiences in both the discipline-specific field of study and interdisciplinary integration. She suggested a continuum of options for content design with the discipline-specific option at one end and the complete program at the other. According to Jacobs, the complete program option is the most integrated form of IC where "students live in the school environment and create the curriculum out of their day-to-day lives" (p. 18). Between the two ends of Jacobs' model are the four design options - parallel, complementary, inter-disciplinary, and integrated day designs - to be used to distinguish different curricular forms most frequently implemented by the K-3 teachers in the study. As Jacobs explains, in the parallel discipline design, teachers sequence their lessons to correspond to lessons in the same area in other disciplines; in the complementary discipline design, teachers bring together related disciplines in a formal unit/course to investigate a theme or topic; in the interdisciplinary design, teachers integrate the full range of disciplines in the school's curriculum into periodic units/courses; and in the integrated day, teachers create a fullday program based primarily on themes and problems emerging from the child's world.

Since the birth of IC, there have been continuous discussions and explorations as to how it benefits student learning. As early as 1984, the National Association for Core Curriculum examined over eighty studies on the effectiveness of integrative programs and concluded that, in almost every case, the students in integrative programs performed well or better on standardized achievement tests than those students from traditional curriculum programs. Many quantitative and qualitative studies have confirmed the effectiveness of IC and overwhelmingly supported that students can benefit from IC in different areas, such as academic achievement, teamwork, ownership, motivation and attitudes (Cviko, McKenney, \& Voogt, 2013; MacMath, Roberts, Wallace, \& Chi, 2009; Lewis \& Shaha, 2003; Zhbanova, Rule, Montgomery, \& Nielsen, 2010). A closer look at the existing literature indicates that a variety of factors may affect IC implementation in schools, including teachers' beliefs in IC, teachers' knowledge and skills in carrying out IC, and many other issues beyond teaching.

\section{Teachers' Beliefs in IC}

A great number of researchers have investigated the effectiveness of IC by comparing the model with the traditional curriculum or analysing a certain integrated unit/course; however, limited attention has been directed towards teachers' beliefs in the effectiveness of IC. Lun's (2006) research about challenges of teaching IC sheds some light on primary school teachers' beliefs in IC. A survey on the theory and practice of IC was administered to 117 teachers currently teaching 1-6 grade levels. Based on the major findings, the researcher concluded that the participating teachers were strongly in 
support of IC implementation. They believed that IC enhanced connections between different subject areas, related classroom learning to real-world experiences, helped improve students' academic performance, and encouraged students' meaningful application of knowledge. Teachers' beliefs in the effectiveness of IC was confirmed and extended by Ozturk and Erden (2010). To explore teachers' perceptions on IC, Otzurk and her colleague conducted a survey questionnaire of 255 female preschool teachers. The study found that teachers had positive beliefs about IC in general. In particular, many teachers perceived IC to be effective in supporting meaningful learning, enriching traditional learning activities, and fostering children's overall development. Quite a number of studies have underscored the importance of teachers' beliefs with regard to educational topics and how these beliefs profoundly affect teachers' decisionmaking processes and teaching practices (Borko \& Putnam, 1996; Kagan, 1992; Richardson, 1994). As Pajares (1992) suggested, any inquiry into teachers' practices should involve a concurrent study on teachers' beliefs. Thus, the study on teachers' beliefs in the effectiveness of IC is of great necessity.

\section{Teachers' Knowledge and Skills on IC}

In addition to teachers' beliefs about the curriculum, teachers' ability to implement curriculum may affect what they bring to the classroom and how they will teach. As Hinde (2005) noted, successful implementations of IC require skilled and knowledgeable teachers. The complexity of using IC challenges both in-service and preservice teachers to develop overall teaching competency, including content knowledge in different subject areas, theoretical knowledge on IC, and pedagogical knowledge of implementing IC.

To effectively teach IC, teachers have to possess adequate knowledge in various subject areas. Studies revealed that improving teachers' content knowledge deserves special attention. Cunningham, Perry, Stanovich and Stanovich (2004) surveyed 722 K-3 teachers' content knowledge in English reading. The findings of the research were disappointing in that the participants, on average, showed very limited knowledge of children's literature, phoneme awareness and phonics. What is worse, it was found that "teachers tend to overestimate their reading-related subject matter knowledge, and are often unaware of what they know and do not know" (p. 140). Teachers' content knowledge in other academic disciplines, such as mathematics, science, and social studies, has also been examined by researchers (Lampert, 1988; Lee, 2010; Wilson \& Wineburg, 1988). For example, Lee's (2010) research focused on exploring kindergarten teachers' content knowledge of mathematics. Through his assessment of 81 teachers' mathematical knowledge in six subcategories, he concluded that although teachers demonstrated relatively higher level of content knowledge in number sense and pattern, they needed further improvement in spatial sense and comparison. In terms of science, Harrell (2010) reported that many teachers are not competent to teach integrated science curriculum due to their insufficient content knowledge needed to teach science. Another study conducted by Lam, Alviar-Martin, Adler, and Sim (2013) reported similar results. The researchers analysed eleven teachers' interview data, and concluded that teachers' inadequate content knowledge in different subject areas 
prevented them from identifying key ideas to be covered in teaching an integrated curriculum.

While the researchers warned us with a red flag of teachers' insufficient content knowledge, Park (2008) echoed that teachers were not yet well prepared in theoretical knowledge on IC, either. All of the in-service elementary teachers interviewed by Park shared a common concern about the absence of theoretical support in their teaching practice. From this, he summarized:

The participant teachers were only partially acquainted with the primary concepts behind the integrative approach, and their understandings of these concepts were largely intuitive and not based on a study of their significance and of the possibilities of applying them to their teaching. They planned activities for integration that were mostly dependent on their intuition and experiences without an appropriate theoretical basis, which affects the essence and quality of integrated curricular development in school. (p. 314)

A more recent study implemented by Araujo and his colleagues (2013) also indicated teachers' lack of theoretical knowledge on IC. Through analysis of focus group and individual interviews from twenty-seven participants, the authors found that teachers demonstrated various understandings of IC. In other words, although implemented the same mandated curriculum, the participants reported quite different perceptions of what the term IC meant in the context of math instruction.

Apart from grappling with inadequate content and theoretic knowledge for curriculum integration, teachers are also challenged to improve their pedagogical knowledge. Richards and Shea (2006) investigated twenty-eight pre-service teachers who taught kindergarteners and first graders in a field-based interdisciplinary program. The two researchers described these teachers' struggles with two pedagogical issues. One was the interweaving of different subject areas into a more cohesive IC framework; the other was the difficulty of preparing lessons in a more creative way. The study not only discovered the problems that pre-service teachers had in conducting IC, but also foresaw the urgent need to examine in-service teachers' pedagogical competencies, which is crucial for IC implementation.

\section{Other Issues beyond Teaching}

There are many other issues that may complicate curriculum integration in $\mathrm{K}-3$ classrooms. Lun's (2006) survey indicated that the biggest barrier of implementing IC was teachers' heavy workload that deprived them of enough planning time. He also pointed out that a major difficulty for carrying out curriculum integration arose from the need for more collaboration between teachers of different subject areas. This collaboration required that teachers are given more compatible working hours to cooperate with each other. Other obstacles for curriculum integration in the early childhood setting have been noted by Park (2008) and $\mathrm{Na}$ (2004), such as lack of resources, student support, parent support and information on IC. 
Similar and different factors that may influence IC implementation have been identified beyond K-3 grade levels. Beane (1995) portrayed how various factors outside the classroom may turn against integration, such as insufficient support from fellow teachers, administrators and parents. Similar findings were reported in Meister and Nolan's (2001) case study which interpreted how five high school teachers were challenged to restructure an interdisciplinary curriculum completely imposed by the administration. The teachers' dilemma in curriculum restructuring included the absence of teacher input into the decision to restructure, lack of professional development, lack of a written curriculum, lack of administrative leadership and the pull between teachers' loyalty to their own subject areas and allegiance to their interdisciplinary team. All these conditions led to teachers' uncertainty and doubt in moving from subject-centered teaching to interdisciplinary teaching and, therefore, made curriculum integration extremely difficult. Likewise, Wallace, Sheffield, Rennie and Venville (2007) have scrutinized conditions that may impact integration. Comparing two case studies of nine Western Australian middle schools over the past decade and interviewing six in-service teachers from these schools, Wallace and his colleagues concluded that there are four conditions affecting curriculum integration. These four conditions are known as "shared purpose," "collegial relations," "norms of improvement," and "the structure." (p. 41) In addition to the factors mentioned above, Owoyemi's (2014) study revealed that students' readiness to learn, teachers' interaction with students, and quality and availability of teaching materials to construct the curriculum all significantly influenced planning and implementation of IC.

\section{Research Aim}

The literature review suggested that a variety of factors may impact teachers' implementation of IC. First, teachers' beliefs about the effectiveness of IC can influence whether teachers want to adopt and use the curriculum in their classrooms. Second, teachers' knowledge and skills on IC not only determines the teaching competence of the curriculum, but also may greatly affect teachers' curriculum decisions. Finally, other factors beyond teachers' control, such as time, resources, and support from students, parents and colleagues, are also critical to the successful implementation of the curriculum. However, in previous studies these factors have often been examined in isolation from each other. And almost no studies have examined the effects of such factors on the frequency and form of IC implementation in early childhood settings. Given these limitations of previous research, the purpose of the current study was to explore the factors that may influence K-3 teachers' decisions to implement IC in their classrooms. In detail, this study was conducted around four research questions:

1. How often do K-3 teachers implement integrated curriculum?

2. What form of integrated curriculum do they most frequently implement?

3. What are the factors that may influence teachers' frequency of implementing the curriculum?

4. What are the factors that may influence teachers' choice of curricular form? 


\section{METHOD}

As stated, this study attempted to discover how the related factors affect K-3 teachers' implementation of Integrated Curriculum (IC) from teachers' perspectives. A survey questionnaire was used to collect mainly quantitative data, including teachers' implementation of IC and various factors that they believe will impact their curriculum decisions.

\section{Participants}

The participants of this study were forty-two K-3 teachers from ten school districts in Ohio. The teacher sample represented a broad range of experience. Specifically, the participants had at least a bachelor's degree with $83.3 \%$ possessing a master's degree. Teachers' age and years of teaching varied greatly, but $61.9 \%$ were in their thirties and $78.6 \%$ had more than five years of primary teaching experience. The teacher sample was spread across the K-3 teaching grade levels, with no single level having fewer than $26.2 \%$. Many participants were teaching more than one subject area, and most of them (78.6\%) taught English Language Arts.

\section{Instrument}

An online survey was used as the instrument for the study. To increase validity and reliability of the instrument, the 34 survey items were constructed based on a systematic literature review. In specific, the content of the survey items was grounded in the findings of previous studies (e.g. Cunningham, Perry, Stanovich, \& Stanovich, 2004; Lee, 2010; Lun, 2006; Na, 2004; Ozturk \& Erden, 2010; Park, 2008) that investigated influencing factors of IC implementation. A broad definition of IC was presented at the beginning of the survey, which provided a clear concept to the participating teachers. To help better analyse the teacher sample, the first seven items were used to collect teachers' demographic information (including gender, degree, age, years of primary teaching, teaching grade levels, subject areas, and school district). The three items that followed focused on teachers' implementation of IC, asking about their frequency of implementing IC and most frequently used form of IC. The final 24 items were designed to explore what factors may impact IC implementation. Specifically, these items were divided into four sections. Section 1(items 11-20) intended to find out teachers' beliefs about the effectiveness of IC. Section 2 (items 21-24) requested teachers to report their knowledge and skills of implementing IC. Section 3 (items 25-33) examined other factors beyond teaching that may affect IC implementation. Section 4 (item 34) was open-ended, allowing teachers to supplement those factors not listed in the survey that influence their curriculum decisions.

\section{Procedures}

To help identify potential problems in the survey and improve its content validity (Gay, Mills, \& Airasian, 2006), a pilot study was conducted before distributing the 
questionnaire to the participants. The researcher had three K-3 in-service teachers read the consent form and complete the survey. Based on their suggestions, the survey was revised to provide more detailed directions and to add an open-ended section at the end of the survey that allowed participants to identify other factors not included in the survey. The end product of this pre-test was converted to an online survey and then distributed to potential participants via an invitation email. A follow-up email was sent out half a month before the survey deadline, which reminded those participants who had not filled out the survey. Once the data were collected, they were exported to SPSS software. Data were analysed quantitatively by employing the methods of descriptive statistics (i.e. percentage, mean, and standard deviation), Pearson's correlations and multiple regressions.

\section{FINDINGS}

The study was designed to explore the factors that influence K-3 teachers' decision of implementing Integrated Curriculum (IC). The following presents the findings around the four research questions, which offers a better understanding about teachers' implementation of IC and the extent to which the related factors may affect their curriculum decisions.

\section{Teachers' Implementation of IC}

Questions concerning teachers' implementation of IC were asked in three items on the survey. Specifically, teachers were requested to report their frequency of implementing IC (item 8) and the form of IC that they most frequently use in their classrooms (items 910). The results showed that $38.1 \%$ of the teachers always implement IC and $26.2 \%$ frequently use it. Conversely, the rest $(35.8 \%)$ implement IC on a less regular basis, which means they seldom, occasionally or never use IC in their teaching. It is also noted that except for one teacher who had no experience with IC, the vast majority have implemented some form of IC in their classrooms. The two most common forms, used by $42.9 \%$ and $40.5 \%$ of the teachers respectively, were Complementary Discipline Unit and Paralleled Discipline Unit. Two less popular forms were Interdisciplinary Unit used by $9.5 \%$ of the teachers and Integrated Day by $4.8 \%$. No other form of IC outside the four listed on the survey was reported by the participants.

\section{Influencing Factors on IC Implementation}

First of all, descriptive data of teachers' responses to survey items 11-33 were reported in Table 1 below, including mean, standard deviation and percentage of each response choice. In section one, the high mean scores and low standard deviations of items 11-20 demonstrated that the participants overwhelmingly held strong beliefs in the effectiveness of IC. The results from items 21-24 in section two showed that most teachers thought they were, in general, competent to implement IC, with $11.9 \%$ strongly agreeing and $83.3 \%$ agreeing that they had good knowledge and skills for curriculum implementation. A closer look at the three knowledge domains revealed that the mean scores of theoretical knowledge (3.81) and pedagogical knowledge (3.95) were lower than that of content knowledge (4.26). Compared to the mean scores in the first two sections, those for section three were much lower (ranging from 2.79 to 3.81), reflecting 
more variation in teachers' attitudes about factors beyond teaching. Among all the items 25-33, teachers marked strongest disagreement with two factors, planning time and compatible working hours with colleagues.

Table 1

Means, Standard Deviations, and Percentages of Items 11-33

\begin{tabular}{llllllll}
\hline $\begin{array}{l}\text { Survey } \\
\text { Item }\end{array}$ & Mean & $\begin{array}{l}\text { Standard } \\
\text { Deviation }\end{array}$ & $\begin{array}{l}\text { Strongly } \\
\text { Agree }\end{array}$ & Agree & $\begin{array}{l}\text { Not } \\
\text { Sure }\end{array}$ & Disagree & $\begin{array}{l}\text { Strongly } \\
\text { Disagree }\end{array}$ \\
\hline 11 & 4.64 & 0.48 & $64.3 \%$ & $35.7 \%$ & $0.0 \%$ & $0.0 \%$ & $0.0 \%$ \\
\hline 12 & 4.71 & 0.46 & $71.4 \%$ & $28.6 \%$ & $0.0 \%$ & $0.0 \%$ & $0.0 \%$ \\
\hline 13 & 4.60 & 0.54 & $61.9 \%$ & $35.7 \%$ & $2.4 \%$ & $0.0 \%$ & $0.0 \%$ \\
\hline 14 & 4.45 & 0.54 & $50.0 \%$ & $45.2 \%$ & $4.8 \%$ & $0.0 \%$ & $0.0 \%$ \\
\hline 15 & 4.36 & 0.66 & $42.9 \%$ & $52.4 \%$ & $2.4 \%$ & $2.4 \%$ & $0.0 \%$ \\
\hline 16 & 4.45 & 0.50 & $45.2 \%$ & $54.8 \%$ & $0.0 \%$ & $0.0 \%$ & $0.0 \%$ \\
\hline 18 & 4.60 & 0.54 & $61.9 \%$ & $35.7 \%$ & $2.4 \%$ & $0.0 \%$ & $0.0 \%$ \\
\hline 19 & 4.45 & 0.59 & $50.0 \%$ & $45.2 \%$ & $4.8 \%$ & $0.0 \%$ & $0.0 \%$ \\
\hline 20 & 4.33 & 0.65 & $42.9 \%$ & $47.6 \%$ & $9.5 \%$ & $0.0 \%$ & $0.0 \%$ \\
\hline 21 & 4.36 & 0.73 & $47.6 \%$ & $42.9 \%$ & $7.1 \%$ & $2.4 \%$ & $0.0 \%$ \\
\hline 22 & 4.05 & 0.49 & $11.9 \%$ & $83.8 \%$ & $2.4 \%$ & $2.4 \%$ & $0.0 \%$ \\
\hline 24 & 3.81 & 0.63 & $7.1 \%$ & $71.4 \%$ & $16.7 \%$ & $4.8 \%$ & $0.0 \%$ \\
\hline 25 & 4.26 & 0.50 & $28.6 \%$ & $69.0 \%$ & $2.4 \%$ & $0.0 \%$ & $0.0 \%$ \\
\hline 26 & 3.95 & 0.49 & $7.1 \%$ & $83.8 \%$ & $7.1 \%$ & $2.4 \%$ & $0.0 \%$ \\
\hline 27 & 3.57 & 0.89 & $7.1 \%$ & $61.9 \%$ & $11.9 \%$ & $19.0 \%$ & $0.0 \%$ \\
\hline 28 & 2.79 & 1.14 & $0.0 \%$ & $35.7 \%$ & $26.2 \%$ & $19.0 \%$ & $19.0 \%$ \\
\hline 29 & 2.95 & 1.08 & $4.8 \%$ & $31.0 \%$ & $28.6 \%$ & $26.2 \%$ & $9.5 \%$ \\
\hline 30 & 3.14 & 0.93 & $2.4 \%$ & $40.5 \%$ & $28.6 \%$ & $26.2 \%$ & $2.4 \%$ \\
\hline 31 & 3.81 & 0.89 & $19.0 \%$ & $54.8 \%$ & $14.3 \%$ & $11.9 \%$ & $0.0 \%$ \\
\hline 32 & 3.81 & 1.09 & $28.6 \%$ & $40.5 \%$ & $19.0 \%$ & $7.1 \%$ & $4.8 \%$ \\
\hline & 3.24 & 0.85 & $7.1 \%$ & $26.2 \%$ & $52.4 \%$ & $11.9 \%$ & $2.4 \%$ \\
\hline
\end{tabular}

As suggested by Stemler (2004), Pearson correlation coefficients were then computed to examine the internal consistency within section one and section two. Even though Table 1 offers detailed descriptive information concerning the results of each individual item, it fails to demonstrate the extent to which the items in each of the first two sections combined together to represent the respective factor. That is, how well items 11-20 together represented the factor of teachers' beliefs in the effectiveness of IC and how items 21-24 together represented the factor of teachers' knowledge and skills in implementing IC. The internal consistency of these items was examined by conducting Pearson's correlations between the score of each item and the total score of these items. The correlation coefficients for all items in section one were highly significant at the 0.01 level, ranging from .64 to .89. Significant correlation coefficients, ranging from .591 to .795 , were also reported between each of the items $21-24$ and the total of all four items $(\mathrm{p} \leq 0.01)$, indicating high internal consistency within section two. Given that strong internal consistency was demonstrated, the average score of items 11-20 and that of items 21-24 were used to statistically represent teachers' overall responses on the respective factors of teachers' beliefs in the effectiveness of IC and teachers' knowledge and skills of implementing IC. 
Finally, the multiple regression analyses were employed to examine the extent to which various factors can predict teachers' implementation of IC. In detail, the forward method (Field, 2009) was used to search for significant predictors. The two outcome variables were teachers' frequency of implementing IC and the form of IC that they used most in classrooms. The predictor variables were teachers' beliefs in the effectiveness of IC, teachers' knowledge and skills in implementing IC, resources, planning time, compatible working hours with colleagues, professional development, administration support, colleague support, parent support, student support and community support. When teachers' frequency of implementing IC was the outcome variable, teachers' planning time and compatible working hours with colleagues were significant predictors at .05 level (see Table 2). These two factors accounted for $69.6 \%$ of the total variance. The positive b-values for planning time and compatible working hours indicated positive relationships. In other words, as teachers' planning time of IC increases, their frequency of implementing IC increases; and as teachers' compatible working hours with other colleagues also increases, so does frequency of implementing IC.

Table 2

Summary of significant predictor variables of IC implementation frequency

\begin{tabular}{llllll}
\hline & $B$ & Beta & $T$ & Sig & $R^{2}$ \\
\hline Constant & 1.156 & & 3.758 & .001 & .696 \\
\hline Planning Time & .545 & .519 & 3.147 & .003 & \\
\hline Compatible Working Hours & .385 & .348 & 2.113 & .041 & \\
\hline
\end{tabular}

When the form of IC was the outcome variable, Community Support, Colleague Support, and Teachers' Knowledge and Skills were found as significant predictors at the significance level of .05 (see Table 3). When all three predictors were included, the model accounted for a total of $31.4 \%$ of the variance in the form of IC implemented by teachers, with Community Support explaining 14.4\%, Colleague Support 8.9\% and Teachers' Knowledge and Skills $8.1 \%$. Additionally, the negative b-values for Community Support (-.507) and Teachers' Knowledge and Skills (-.699) indicated that the more community support the teachers have, the less likely they will use the more integrated forms of IC; the more knowledge and skills teachers have, the less likely they will use the more integrated curricular form. The b-value for Colleague Support is .247, showing a positive relationship between the predictor and outcome variables. Simply, the more colleague support teachers can receive, the more likely they are to use a more integrated form of IC during their teaching practice.

Table 3

Summary of significant predictor variables of most frequent IC form

\begin{tabular}{llllll}
\hline & $B$ & Beta & $T$ & Sig & $R^{2}$ \\
\hline Constant & 6.49 & & 4.735 & .000 & .314 \\
& 8 & & & & \\
\hline Community Support & -.572 & -.430 & -2.970 & .005 & \\
\hline Colleague Support & .247 & .314 & 2.204 & .034 & \\
\hline Knowledge and Skills & -.696 & -.290 & -2.119 & .041 & \\
\hline
\end{tabular}




\section{DISCUSSION AND IMPLICATIONS}

Although the superiority of Integrated Curriculum (IC) over the traditional curriculum has been widely supported in the existing literature (e.g. Zhbanova, Rule, Montgomery, \& Nielsen, 2010), the potential educational benefits of IC cannot be realized without teachers' successful implementation of it in their classrooms. The study results expanded our understanding on how IC is being used in early childhood education settings.

Firstly, the study revealed that teachers almost unanimously believed in the effectiveness of IC and demonstrated high levels of confidence in their knowledge and skills of curriculum integration. Yet, their agreement levels about other factors that may influence IC implementation vary. These results echoed the findings of previous research (Lun, 2006; Ozturk \& Erden, 2010) that early childhood teachers generally have strong beliefs that IC can benefit student learning in multiple ways. An interesting discrepancy between the existing literature and current study is related to teachers' selfreflection of their knowledge and skills on IC. While some researchers (Lee, 2010; Park, 2008; Richards \& Shea, 2006) concluded that teachers' knowledge on IC was underdeveloped, this study found that teachers, in general, think they possess proper knowledge and skills in teaching IC. Since teachers were self-reporting, they may have inadvertently misreported or overestimated their competency, as suggested by Cunningham, Perry, Stanovich and Stanovich (2004). The gap between teachers' actual abilities and beliefs of their knowledge and skills demands further investigations.

Secondly, the current analysis of the teacher survey data confirmed the importance of teachers' planning time and compatible working hours with their colleagues as critical factors affecting teachers' curriculum decision, as stated in Lun's work (2006). Further, this study identified planning time and compatible working hours as two strong predictors of teachers' frequency of using IC in the classroom. Planning an integrated curriculum is not an easy task, since it takes considerable preparation time and requires collaboration from teachers in various disciplines. The intensification and extension of teachers' workload often stress teachers with excessive administration and clerical work and decrease their time spent on teaching or teaching-related tasks (Campbell \& Neill, 1992, 1994). To enhance frequency of implementing IC, school administrators should consider adjusting teachers' workload to allow more planning time and teacher team work. On the teachers' part, they should strive to take full use of their working time, improve skills in work management, and actively seek opportunities to collaborate with their colleagues.

Thirdly, the findings suggested that although most teachers implemented IC on a regular basis, they preferred to use less integrated forms of IC (based on Jacobs' model), i.e. Paralleled Discipline Design and Complementary Discipline Unit. The variance in teachers' choice of curriculum forms can be moderately predicted by three factors, which are Community Support, Colleague Support and Teachers' Knowledge and Skills. The positive relationship between teachers' knowledge and skills and the form of IC they adopted indicated that teachers with inadequate knowledge and skills on IC tended 
to use less integrated form, because they may not well know how to implement more integrated forms of IC. Due to the fact that most teacher education programs in the U.S. are structured around separate courses in subject areas (Darling-Hammond, 2006), it is not surprising at all to find that many teachers' competence to design and implement IC is underdeveloped. This demands teacher educators to seek an alternative approach to reconceptualise the structure of the existing programs and engage pre-service teachers in interdisciplinary teaching which will break the boundaries between individual content areas. To cultivate quality future educators, pre-service teachers should develop a clear understanding about the meaning of IC; they also need to be exposed to different forms of IC, so that they can differentiate among them, study the characteristics of each, and practice on using diverse curricular forms to enhance instruction and learning outcomes.

It is also interesting to note that the more support that teachers received from the community and their colleagues, the less integrated form of IC they would use. This may be partly explained by the fact that the less integrated curricular form was more popular than their more integrated counterparts, since they are much easier to be planned and implemented. However, the in-depth reasons of why community support and colleague support negatively influenced the level of curriculum integration need to be further probed.

\section{RECOMMENDEIONS}

Despite its educational significance, the study is not without limitations and can be improved in the following aspects. First, the sample size of the study is small, and all the 42 participants are K-3 teachers currently employed by public elementary schools in the U.S. Therefore, the generalization level of the study may be limited by the participants' demographic characteristics and sample size. This challenges future researchers to carry out large-scale studies by recruiting early childhood teachers with more diverse backgrounds across the country. Secondly, the discussion above indicated that some other significant predictors are not included in the survey questionnaire. To provide a more accurate understanding of the topic, research efforts need to centre on the factors, not included in the current study, which may impact K-3 teachers' implementation of IC. Another limitation is that less than comprehensive data types are used to address the research question. More qualitative data, such as classroom observations, lesson plans and interviews could be employed to help gather more in-depth information on the topic. The mixed methods design would not only take advantage of the synergy and strength of both qualitative and qualitative research methods (Gay, Mills, \& Airasian, 2006) but also help gain a more comprehensive understanding of the related factors that may influence K-3 teachers' implementation of IC and how these factors affect teachers' curricular decisions. Last but not least, if we look beyond teachers' perspectives, what other voices should be heard with regard to IC? For example, how do principals, students and their parents perceive the various factors that may affect the IC being used in early childhood classrooms? 


\section{REFERENCES}

Araujo, Z., Jacobson, E., Singletary, L., Wilson, P., Lowe, L., Marshall, A. M. (2013). Teachers' conceptions of integrated mathematics curricula. School Science and Mathematics, 113 (6), 285-296.

Beane, J. A. (1995). Introduction: What is a coherent curriculum? In J. A. Beane (Ed.), Toward a coherent curriculum. Alexandria, VA: Association for Supervision and Curriculum Development.

Borko, H., \& Putnam, R. T. (1996). Learning to teach. In D. C. Berliner \& R. C. Calfee (Eds.), Handbook of educational psychology (pp. 673-708). New York, NY: Macmillan.

Campell, R. J., \& Neill, S. R. (1992). The use and management of secondary teachers' time after the Education Reform Act 1988. Warwick: Warwick University.

Campell, R. J., \& Neill, S. R. (1994). Secondary teachers at work. London: Paul Chapman.

Cviko, A., McKenny, S., \& Voogt, J. (2013). The teacher as re-designer of technology integrated activities for early literacy curriculum. Journal of Educational Computing Research, 48(4), 447-468.

Creswell, J. W. (2008). Educational research: Planning, conducting, and evaluating quantitative and qualitative research. Boston, MA: Pearson.

Cunningham, A. E., Perry, K. E., Stanovich, K. E., \& Stanovich, P. I. (2004). Disciplinary knowledge of K-3 teachers and their knowledge calibration in the domain of early literacy. Annals of Dyslexia, 54(1), 139-167.

Czerniak, C. M., Weber, W. B., Sandmann, A., \& Abhern, J. (1999). A literature review of science and mathematics integration. School Science and Mathematics, 99(8), 421430 .

Darling-Hammond, L. (2006). Constructing $21^{\text {st }}$-century teacher education. Journal of Teacher Education, 57(3), 300-314.

Field, A. (2009). Discovering Statistics Using SPSS. London: Sage Publications.

Gay, L. R., Mills, G. E., \& Airasian, P. (2006). Educational research: Competencies for analysis and applications. New Jersey: Pearson Education.

Gehrke, N. J. (1998). A look at curriculum integration from the bridge. Curriculum Journal, 9(2), 247-260.

Harrell, P. E. (2010). Teaching an integrated science curriculum: Linking teacher knowledge and teaching assignments. Issues in Teacher Education, Spring, 145-165.

Hinde, E. R. (2005). Revisiting curriculum integration: A fresh look at an old idea. Social Studies, 96(3). 
Hough, D. L., \& Clair, B. (1995). The effects of integrated curricula on young adolescent problem-solving. Research in Middle Level Education Quarterly, 19(1), 125.

Jacobs, H. H. (1989). Interdisciplinary curriculum: Design and implementation. Alexandria, VA: Association for Supervision and Curriculum Development.

Kagan, D. M. (1992). Implication of research on teacher belief. Educational Psychology, 27, 65-90.

Lam, C. C., Alviar-Martin, T., Adler, S. A., \& Sim, J. B. (2012). Curriculum integration in Singapore: Teachers' perspectives and practice. Teaching and Teacher Education, 31, 23-34.

Lampert, M. (1988). What can research on teacher education tell us about improving quality in mathematics education? Teaching and Teacher Education. 4, 157-170.

Lee, J. (2010). Exploring kindergarten teachers' pedagogical content knowledge of mathematics. International Journal of Early Childhood, 42, 27-41.

Lewis, V. K., \& Shaha, S. H. (2003). Maximizing learning and attitudinal gains through integrated curricula. Education, 123(3), 537-547.

Lun, W. (2006). Teach integrated curriculum: Teachers' challenges. Pacific-Asian Educational Journal, 18(1), 88-102.

MacMath, S., Roberts, J., Wallace, J., \& Chi, X. (2009). Curriculum integration and atrisk students: A Canadian case study examining student learning and motivation. British Journal of Special Education, 37(2).

Martinello, M. L., \& Cook, G. E. (1994). Interdisciplinary inquiry in teaching and learning. NY: Macmillan College Publishing Company.

Meeth, L. R. (1978). Interdisciplinary studies: Integration of knowledge and experience. Change, 10, 6-9.

Meister, D. G., \& Nolan J. (2001). Out on a limb on our own: Uncertainty and doubt in moving from subject-centered to interdisciplinary teaching. Teachers College Record, 103(4), 608-633.

$\mathrm{Na}$, J. (2004). Elementary school teachers' understandings on curriculum integration. The Korean Journal of Curriculum Studies, 22(1), 101-124.

Orillion, M. F. (2009). Interdisciplinary curriculum and student outcomes: The case of a general education course at a research university. The Journal of General Education, $58(1)$.

Owoyemi, T. E. (2014). Effect of professionalism on teachers' perception of integrated science curriculum. Journal of Educational Review, 7(3), 391-401. 
Ozturk, E., \& Erden, F. T. (2011). Turkish preschool teachers' beliefs on integrated curriculum: integration of visual arts with other activities. Early Childhood Development and Care, 181(7), 891-907.

Pajares, M. F. (1992). Teachers' beliefs and educational research: Cleaning up a messy construct. Review of Educational Research, 62(3), 307-332.

Park, M. (2008). Implementing curriculum integration: The experiences of Korean elementary teachers. Asia Pacific Education Review, 9(3), 308-319.

Richards, J. C., \& Shea, K. T. (2006). Moving from separate subject to interdisciplinary teaching: The complexity of change in a preservice teacher K-1 early field experience. The Qualitative Report, 11(1), 1-19.

Richardson, V. (1994). The consideration of teachers' beliefs. In V. Richardson (Ed.), Teacher change and the staff development process: A case in reading instruction (pp.90-108). New York: Teachers College Press.

Shoemaker, B. (1989). Integrative education: A curriculum for the twenty-first century. Oregon School Study Council, 33(2).

Stemler, S. E. (2004). A comparison of consensus, consistency, and measurement approaches to estimating interrater reliability. Practical Assessment, Research \& Evaluation, 9(4). Retrieved August 3, 2015 from http://PAREonline.net/getvn.asp?v=9\&n=4

Vars, G. F. (1993). Interdisciplinary teaching: Why and how. Ohio: National Middle School Association.

Wallace, J., Sheffield, R., Rennie, L., \& Venville, G. (2007). Looking back, looking forward: Re-searching the conditions for curriculum integration in the middle years of schooling. The Australian Educational Researchers, 34(2).

Wallace, J., Venville, G., \& Rennie, L. J. (2005). Integrating the curriculum. In D. Pendergast, \& N. Bahr (Eds), Teaching middle years:Rethinking curriculum, pedagogy and assessment. Sydney: Allen and Unwin.

Wilson, S. M., \& Wineburg, S. S. (1988). Peering at history through different lenses: The role of disciplinary perspectives in teaching history. Teachers College Record, 89, 525-539.

Zhbanova, K. S., Rule, A. C., Montgomery, S. E., \& Nielsen, L. E. (2010). Defining the difference: Comparing integrated and traditional single-subject lessons. Early Childhood Education Journal 38, 251-258. doi: 10.1007/s10643-010-0405-1. 


\section{Turkish Abstract \\ Öğretmenlerin Bakış Açısıyla: K-3 Sınıflarında Bütünleştirilmiş Program Uygulamasını Etkileyen Faktörler}

Bu çalışmanın amacı, öğretmenlerin K-3 sınıflarında kullandıkları bütünleștirilmiş programı (IC) etkileyen faktörleri ortaya çıkarmaktır. Uygun araştırma tabanını sağlamak için, bütünleştirilmiş programın geniş bir tanımı yapılmış ve bütünleştirilmiş programin tartışmalı kısımlarını açıklığa kavuşturmak için Jacob Modeli uygulanmıştır. Anket verileri Ohio'daki 10 okuldaki 42 öğretmenden toplanmıştır. Sonuçlar çoğu öğretmenin bütünleştirilmiş programı temel düzeyde uyguladığını bunula beraber programın daha az bütünleştirilmiş program kullanmayı tercih ettiklerini göstermiştir. Buna ek olarak bu çalışma öğretmenlerin çoğunlukla bütünleştirilmiş programın etkili olduğuna inanmalarına ve bütünleştirilmiş program hakkındaki bilgilerine ve programı uygulama becerilerine rağmen bütünleştirilmiş program uygulamalarını farklılaştıran başka faktörler olabileceği konusunda uzlaşmışlardır. Öğretmenin planlama zamanı ve meslektaşlarıyla uyum içinde çalışması bütünleştirilmiş programın kullanılma sıklığını belirleyen önemli bir gösterge olarak tanımlanmıştır. Veli desteği, meslektaşların desteğinin ve öğretmenin bütünleştirilmiş program uygulamasıyla ilgili bilgi ve becerisinin K-3 sınıflarında eğitim veren öğretmenlerin bütünleştirilmiş uygulama kullanma sıklığını kısmen etkilediği bulunmuştur. Eğitimsel uygulamalar ve gelecekteki araştırmalar için öneriler tartışılmıştır.

Anahtar Kelimeler: bütünleştirilmiş program, faktörler, program uygulaması, öğretmenlerin bakış açısı, erken çocukluk

\section{French Abstract}

Les perspectives de Professeurs: les Facteurs qui Impactent la Mise en oeuvre de Programme d'études Intégré dans des Salles de classe K-3

Le but de cette étude était de découvrir les facteurs qui peuvent influencer la mise en œuvre des professeurs en cours d'emploi k-3 de programme d'études intégré (IC). Pour fournir une base de recherche cohérente, la large définition d'IC et le modèle de Jacob a été adoptée pour clarifier le concept controversé d'IC. Les données d'enquête ont été rassemblées de quarante-deux professeurs de dix secteurs scolaires à l'Ohio. Les résultats ont montré que la plupart des professeurs ont mis en oeuvre l'IC régulièrement; cependant, ils ont préféré utiliser les formes moins intégrées du programme d'études. De plus, l'étude a révélé que quoique les professeurs cru à une grande majorité en efficacité d'IC et leur propre connaissance et compétences sur IC, leurs niveaux d'accord d'autres facteurs qui pourraient affecter la mise en œuvre IC diverse. Le temps de planification des Professeurs et des heures de travail compatibles avec leurs collègues ont été identifiés comme les prophètes significatifs affectant la fréquence des professeurs d'utiliser IC. Le support communautaire, le support de collègue et la connaissance des professeurs et les compétences de mettre en œuvre IC ont été trouvés pour modérément influencer la forme d'IC le plus fréquemment adopté par ces professeurs k-3. Des implications éducatives et des recommandations pour la recherche future sont discutés.

Mots Clés: programme d'études intégré, facteurs, mise en œuvre de programme d'études, les perspectives de professeurs, petite enfance 


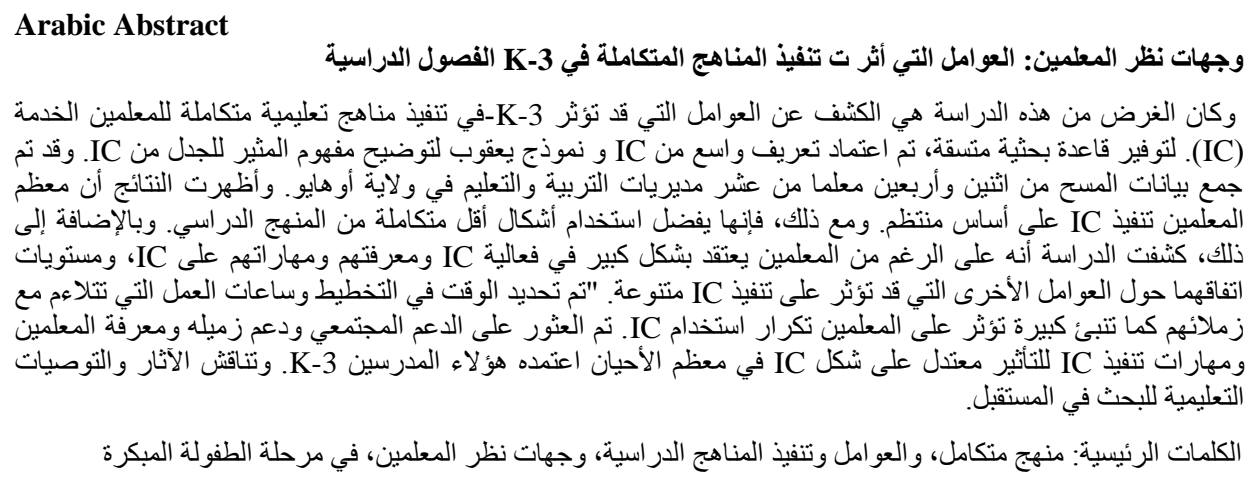

\section{German Abstract}

Lehrerperspektiven: Faktoren, die Auswirkungen der Umsetzung der integrierten Lehrplan in K-3 Klassenzimmer

Der Zweck dieser Studie war es, die Faktoren, die K-3 in-Service-Lehrer die Umsetzung der integrierten Lehrplan (IL) beeinflussen können, aufzudecken. Um eine konsistente Forschungsbasis zur Verfügung zu stellen, wurde die breite Definition von IL und Jacobs Modell angenommen, um das umstrittene Konzept der IL zu klären. Umfrage Daten wurden von zweiundvierzig Lehrer aus zehn Schulbezirke in Ohio gesammelt. Die Ergebnisse zeigten, dass die meisten Lehrer IL regelmäßig einführten; Jedoch bevorzugten sie weniger integrierte Formen des Curriculums. Darüber hinaus zeigte die Studie, dass, obwohl Lehrer überwiegend an die Wirksamkeit der IL und ihre eigenen Kenntnisse und Fähigkeiten auf IL glaubten, ihre Vereinbarungen über andere Faktoren, die Auswirkungen auf die IL-Umsetzung unterschiedlich. Die Planungszeit der Lehrkräfte und die vertrauenswürdigen Arbeitszeiten mit ihren Kollegen wurden als signifikante Prädiktoren für die Häufigkeit von Lehrkräften bei der Verwendung von IC identifiziert. Die Unterstützung durch die Gemeinschaft, die Unterstützung durch die Kollegen und die Kenntnisse und Fertigkeiten der Lehrkräfte bei der Umsetzung der IL wurden als mäßig für die von den K-3-Lehrern am häufigsten angewandten Form der IL angesehen. Pädagogische Implikationen und Empfehlungen für die zukünftige Forschung werden diskutiert.

Schlüsselwörter: integriertes curriculum, faktoren, curriculumsimplementierung, lehrerperspektiven, frühe kindheit 


\section{Malaysian Abstract Perspektif Guru: Faktor Implikasi Pelaksanaan Kurikulum Bersepadu di Bilik Darjah K-3}

Tujuan kajian ini adalah untuk mendedahkan faktor-faktor yang boleh mempengaruhi K-3 guru dalam perkhidmatan terhadap pelaksanaan kurikulum bersepadu (IC). Menyediakan asas penyelidikan yang konsisten, definisi yang luas berkaitan IC dan Jacob's model telah diterima pakai untuk menjelaskan konsep kontroversi berkaitan IC. Data kajian telah dikumpulkan daripada 42 guru dari sepuluh sekolah daerah Ohio. Hasil kajian menunjukkan bahawa kebanyakan guru melaksanakan IC secara tetap; Walau bagaimanapun, mereka lebih suka untuk menggunakan borang kurikulum kurang bersepadu. Di samping itu, kajian menunjukkan bahawa walaupun guru amat percaya kepada keberkesanan IC dan pengetahuan mereka sendiri dan kemahiran mengenai kad pengenalan, tahap persetujuan mereka mengenai faktor-faktor lain yang mungkin memberi kesan kepada pelaksanaan IC diubah. Perancangan masa dan waktu kerja yang sesuai dengan rakan-rakan mereka telah dikenal pasti sebagai peramal utama yang menjejaskan kekerapan guru menggunakan IC. Sokongan masyarakat, sokongan rakan sekerja dan pengetahuan guru dan kemahiran melaksanakan IC didapati sederhana mempengaruhi bentuk IC yang paling kerap digunakan oleh guru K-3. implikasi pendidikan dan cadangan untuk kajian akan datang dibincangkan.

Kata Kunci: kurikulum bersepadu, faktor-faktor, pelaksanaan kurikulum, perspektif guru, awal kanak-kanak

\section{Russian Abstract \\ C Точки Зрения Учителя: Факторы, Воздействующие на Осуществление Комплексной Учебной Программы в К-3 Классах}

Цель данного исследования состояла в том, чтобы отрыть факторы, которые может влиять на К-3 реализации учителей интегрированного учебного плана (IC). Предоставлять последовательное научно-исследовательскую базу, широкое определение IC и Иакову модель были приняты, чтобы разъяснить спорную концепцию IC. Данные исследования были собраны из сорока двух учителей из десяти школьных округов в Огайо. Результаты показали, что большинство учителей реализованы IC на регулярной основе; тем не менее, они предпочтительный использовать менее интегрированного формы учебного плана. Кроме того, исследование показало, что, хотя учителя в подавляющем большинстве случаев верили в эффективности IC и свои собственные знания и навыки по IC, их уровни соглашения о других факторах которые могут повлиять на реализацию IC разнообразных. Учителей время планирования и совместимых рабочих часов со своими коллегами были идентифицированы как значимые предикторы, влияющие учителей частоту использования IC. Поддержка сообщества, поддержка коллег и знания учителей и навыки из внедрения IC были найдены умеренно влиять из форму IC большинство часто принятый от те К-3 учителей. Образовательные последствия и рекомендации для будущих исследований обсуждаются.

Ключевые Слова: интегрированная учебная программа, факторы, реализация учебных программ, перспективы учителей, раннего детства 